\title{
ENTRE O VERBAL E O NÃO-VERBAL: UMA ANÁLISE SEMIÓTICA DE TEXTOS PUBLICITÁRIOS
}

\section{Élisson Ferreira Morato}

RESUMO: este trabalho tem o objetivo de demonstrar a eficácia da teoria semiótica de linha francesa na análise de textos que se utilizam, principalmente, da visualidade como forma de expressão. Com essa finalidade, analisamos dois textos publicitários recorrendo aos conceitos semióticos de plano de conteúdo e percurso gerativo de sentido. Na perspectiva da semiótica, os textos podem ser verbais, não-verbais, ou sincréticos, quando reúnem mais de um tipo de expressão, e possuem invariavelmente uma rede interna de estruturas geradoras de sentido, dispostas no chamado percurso gerativo de sentido, em três níveis: o nível fundamental, o nível narrativo e o nível discursivo. A análise dessas estruturas, e dos elementos com os quais elas são preenchidas, nos mostra quão rico de significação pode ser um texto de aparente simplicidade.

PALAVRAS-CHAVE: significação; plano de conteúdo, percurso gerativo de sentido; textos sincréticos.

ABSTRACT: in this work, we intend to show the efficacity of the semiotical theory of French line in the analysis of texts that use, primarily, a visual expression. With this purpose, we analyze two publicity texts using the semiotic concepts of content plan, generative course of meaning, and expression plan. According to the perspective of the semiotical theory, the texts may be verbal, nonverbal, or syncretic, when assembling more than one type of expression, and invariably have an internal structure of generate meaning, arranged in the pathway called generative course of meaning, organized in three levels: the fundamental level, the narrative level and the discursive level. The analysis of these structures, and elements with which they are fulfilled, shows how rich of meaning can be a string of apparent simplicity.

KEY-WORDS: meaning, content plan, generative course of meaning, syncretic texts.

Atualmente, podemos observar a existência de um grande número de gêneros textuais. Gênero textual é um conjunto de textos produzidos dentro de um contexto social específico, 
contexto que determina muitas de suas características quanto ao uso da linguagem e apresentação gráfica. Podemos citar como exemplo anúncios publicitários, em que a imagem adquire importância cada vez maior, como se o primado da palavra perdesse, progressivamente, espaço para elementos visuais. Em alguns casos, palavra e imagem são trabalhadas uma em complemento com a outra, em outros, o anúncio parece abdicar quase que completamente do signo verbal, deixando ao leitor a tarefa de interpretar os elementos visuais.

Mas a onipresença da imagem não implica em um esvaziamento de sentidos, como se os elementos visuais fossem incapazes de sugerir significados. E, embora as ciências da linguagem enfatizem o significante verbal como foco de atenção, não podemos deixar de levar em conta a expressividade e o potencial de significação dos elementos visuais, já que, em alguns casos, o significante visual complementa a significação do texto, e, em outros, é (são) o próprio texto.

Este trabalho, portanto, tem o objetivo de demonstrar os processos de significação em textos nos quais ocorre uma conciliação de códigos verbal e icônico, textos assim definidos como sincréticos pela teoria que utilizamos neste estudo: a semiótica de linha francesa, também conhecida como semiótica textual ou greimasiana, que tem esse nome devido ao seu fundador, o lituano Algirdas Julien Greimas, autor debitário da linguística estrutural de Ferdinand Saussure e de Louis Hjelmslev. Utilizamos na análise de nosso objeto os conceitos greimasianos de "plano de conteúdo" e "percurso gerativo de sentido" e "plano de expressão”, embora este último receba uma exposição bastante sucinta.

Para a realização de nossos objetivos, analisamos dois textos publicados na revista Época, o primeiro em setembro e o segundo em outubro de 2009. Trata-se de dois anúncios publicitários nos quais podemos perceber, no primeiro texto, a ausência parcial de significantes verbais e, no segundo, a ausência total, ou quase total de significantes verbais.

A semiótica é uma teoria linguística debitária das ideias estruturalistas de Ferdinand Saussure e de Louis Hjelmslev. De Saussure, a teoria greimasiana herdou clássica dicotomia significante e significado, e de Hjelmslev a também dicotomia conteúdo e expressão (HJELMSLEV, 1968, p. 66). Como uma teoria interessada na significação do texto, a semiótica elaborou o conceito de plano de conteúdo a partir da noção saussureana de significado, e da hjelmsleviana de conteúdo. Por sua vez, o conceito de plano de expressão, foi elaborado a partir da ideia de significante, saussureano e de expressão, hjelmsleviana.

Desse modo, a semiótica, tendo a significação como objeto de estudo e o texto como unidade de análise, lega o conceito de texto como a junção entre um plano de conteúdo com 
um plano de expressão. Dessa junção, temos textos verbais, não-verbais, como a pintura, a escultura e a fotografia, e os textos chamados de sincréticos, que utilizam-se de dois ou mais códigos de expressão, como o cinema, quadrinhos, o teatro, e muitos exemplares de publicidade.

Na teoria greimasiana, conteúdo e expressão distinguem como que duas etapas ou dois planos de significação específicos, mas interdependentes. Mas enquanto o plano de conteúdo já se solidamente constituído na teoria semiótica e largamente estudado, o plano de expressão ainda não se encontra plenamente concebido. Parte da dificuldade de se estabelecer um plano de expressão segundo parâmetros fixos é resultado das particularidades de cada texto, já cada qual pode ter uma expressão verbal, icônica, gestual, entre outras.

Para a semiótica, todo texto é dotado de uma estrutura interna organizada como uma narrativa. Entretanto, narrativa não deve ser entendida como mera descrição de fatos em uma sequência, mas como uma mudança de estado sofrida ou executada pelos sujeitos, ou, em termos semióticos, actantes, sujeitos que, em uma narrativa, executam ou sofrem a ação, inscritos no texto. Essa narratividade é depreendida dentro de um conjunto de estruturas de significação que, organizadas hierarquicamente, formam o percurso gerativo de sentido. Por seu turno, é um modelo que permite ao pesquisador/analista observar a atividade de construção de sentido do discurso, um simulacro teórico-metodológico em que temos uma representação hipotética das articulações dos mecanismos semióticos.

A noção de percurso sugere necessariamente que a significação se constrói através de etapas ou níveis que partem da mais simples e abstrata e culminam com a mais complexa e concreta, perpassando assim três níveis: o nível fundamental, o nível narrativo e o nível discursivo. O percurso gerativo de sentido, com os níveis fundamental, narrativo e discursivo, forma o plano de conteúdo do texto, que pode ser definido como “o lugar dos conceitos ou “onde o texto diz o que diz” (HERNANDES, 2005, p. 228).

No nível fundamental, o mais profundo, encontramos conceitos fundamentais organizados em uma oposição do tipo $a$ versus $b$, conceitos opostos e que, ao mesmo tempo, se pressupõem mutuamente, como morte vs vida, natureza vs cultura, humanidade vs divindade. Esses pares, mais do que termos antônimos, são conceitos fundamentais presentes na cultura e capazes de se manifestar em um número incalculável de textos. Ainda no nível fundamental, essas oposições semânticas se organizam no/pelo chamado quadrado semiótico, representação visual da articulação lógica de uma categoria semântica qualquer (GREIMAS; COURTÉS,1979, p 29-30), da seguinte maneira: 


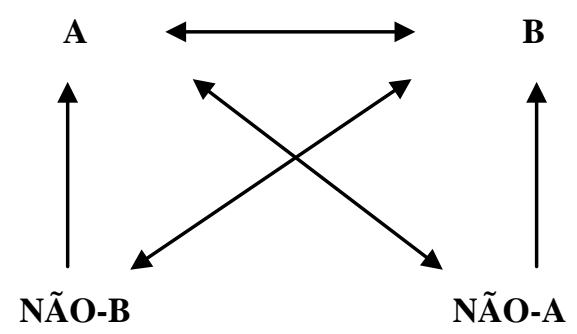

A disposição desses termos no quadrado semiótico segue uma organização que permite visualizar a dinamicidade narrativa presente no texto. $\mathrm{O}$ que podemos notar quando, ao negar um dos termos, temos a asserção de outro, estabelecendo uma percursividade. $\mathrm{O}$ quadrado semiótico “constitui, assim, no nível profundo, a forma primeira das estruturas que, num nível mais superficial, se desdobrarão em arquitetura narrativa” (BERTRAND, 2003, p. 179).

A passagem de um termo ao outro, por seu turno é gradual, importando dizer, nesse caso, que um estado representado por $B$, por exemplo, é precedido, antes de tudo, por um estado Não-A. Dessa maneira, percebemos no texto, uma mudança de estado dos actantes

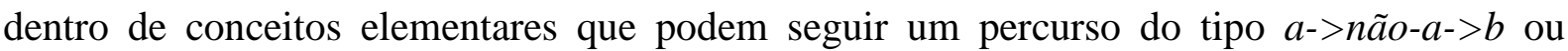
$b>$ não- $b>a$, conforme mostrado a seguir:

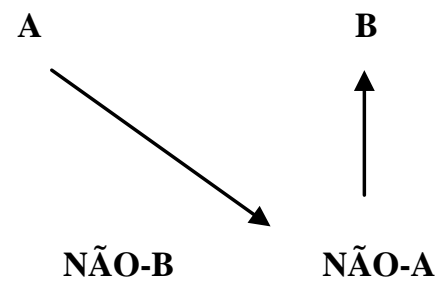

É conveniente lembrar que nem sempre os termos com os quais o quadrado semiótico é preenchido são explicitados no texto. Assim, podemos, na análise de um texto, encontrar 
nitidamente um termo A ou B sem que possamos encontrar traços evidentes de seu oposto. Nesse caso, um dos termos é recuperado através de pressuposição (cf. GREIMAS, COURTES, 1979, p.383).

Os termos do quadrado semiótico, por sua vez, são revestidos de valores, axiologizações positivas ou negativas sendo projetadas sobre elas a relação euforia vs disforia. Se um termo recebe uma axiologização negativa, ele é disfórico, se positiva, é eufórico. Em uma narrativa, o actante busca um estado de conjunção com um objeto eufórico, que é positivo. No momento em que os termos do quadrado semiótico sofrem essa axiologização, cada um deles é representado por um objeto-valor (Ov), de modo a entrarmos, nessa etapa, na configuração do nível narrativo do texto.

O nível narrativo é o mais complexo e o mais amplamente desenvolvido no percurso gerativo de sentido, por essa razão optamos por uma abordagem mais sucinta dessa etapa, relevando os aspectos que consideramos essenciais para a compreensão e análise dos textos selecionados para este trabalho.

No nível narrativo, temos a simulação de um fazer do homem sobre o mundo. O que significa que há um programa narrativo $(\mathrm{PN})$, o qual é o conjunto de ações sofridas e/ou executada pelo sujeito da narrativa, que nos permite entender a ação do sujeito inscrito no texto. O programa narrativo, de maneira geral, segue as seguintes etapas:

1) o actante é manipulado, através de sedução, tentação, intimidação ou provocação, por um destinador-manipulador

2) o actante, que é o destinatário-sujeito da manipulação, acredita ter o poder de executar uma performance;

3) o destinatário-sujeito executa uma performance;

4) um destinador-julgador sanciona a performance do destinatário-sujeito em dois níveis: o cognitivo, reconhecendo que a performance foi executada, e o pragmático, concedendo-lhe uma espécie de premiação ou punição.

O que ilustramos da seguinte maneira:

\section{QUADRO 1:}

\begin{tabular}{|c|c|c|c|c|}
\hline \multirow{5}{*}{$\begin{array}{l}\text { PROGRAMAS } \\
\text { NARRATIVOS }\end{array}$} & MANIPULAÇÃO & \multirow[t]{5}{*}{ COMPETÊNCIA } & \multirow[t]{5}{*}{ PERFORMANCE } & SANÇÃO \\
\hline & TENTAÇÃO & & & \multirow[t]{2}{*}{ COGNITIVA } \\
\hline & SEDUÇÃO & & & \\
\hline & INTIMIDAÇÃO & & & \multirow[t]{2}{*}{ PRAGMÁTICA } \\
\hline & PROVOCAÇÃO & & & \\
\hline
\end{tabular}




\begin{tabular}{|l|l|l|l|l|}
\hline ACTANTES & $\begin{array}{l}\text { DESTINADOR- } \\
\text { MANIPULADOR }\end{array}$ & $\begin{array}{l}\text { DESTINATÁRIO- } \\
\text { SUJEITO }\end{array}$ & $\begin{array}{l}\text { DESTINATÁRIO- } \\
\text { SUJEITO }\end{array}$ & $\begin{array}{l}\text { DESTINADOR- } \\
\text { JULGADOR }\end{array}$ \\
\hline
\end{tabular}

Com a sequência narrativa articulada, temos o nível seguinte, o da enunciação, que trata de relação do enunciador com seu dizer e também da colocação da narrativa em temas e figuras. A enunciação é feita através das categorias de pessoa, espaço e tempo, por meio da debreagem, que consiste na operação pela qual a enunciação se projeta no enunciado, seja como um eu-aqui-agora (debreagem enunciativa), seja como um ele-lá-então (debreagem enunciva) (Greimas; Courtès, 1979, p.119), ou da embreagem, que será explicada mais adiante.

De modo geral, os efeitos de sentido nas operações de debreagem podem ser resumidos como objetividade e subjetividade. Na debreagem enunciativa, por exemplo, o enunciador se coloca como uma instância presente e explícita na enunciação, criando, com isso, um efeito de sentido de subjetividade. Já na debreagem enunciva, ao contrário, a presença do enunciador é pressuposta, ou implícita, traduzindo-se num efeito de objetividade, que pode ainda trazer um efeito de verdade impessoal e atemporal pela ausência do enunciador.

Conforme dissemos anteriormente, além da debreagem enunciativa e da enunciva, temos a embreagem, que é o efeito através do qual um enunciador em primeira pessoa (EU) faz referência a si mesmo como sendo uma terceira pessoa. Esse procedimento é bastante recorrente em textos publicitários e poderia ser exemplificado com uma frase do tipo "As lojas X oferecem o melhor para seus clientes”, sendo que as Lojas X são o enunciador dessa frase, mas referem-se a si mesmas como uma pessoa fora do discurso.

É importante ainda atentarmos para as noções de tema e de figura. Conforme, Fiorin (1999, p. 9) os temas são termos abstratos, que organizam, classificam, categorizam os elementos do mundo natural (beleza, vergonha, inteligência, vaidoso etc) e figuras são termos concretos, que possuem um correspondente perceptível no mundo natural, quer seja este dado ou construído (árvore, sol, correr, brincar, vermelho, frio etc). Assim, os temas remetem a conceitos abstratos, mas que podem ser “recobertos” por figuras, através da figurativização, processo através do qual os temas são trabalhados através de palavras que constroem um simulacro do mundo natural.

Após discorrermos sobre o plano de conteúdo, lembramos que o plano de expressão é formado pelo conjunto de elementos através do qual o texto é expresso. Esse plano, no caso é percebido sem maiores dificuldades pelo leitor do texto através do reconhecimento de 
imagens e/ou palavras, como podemos observar nos exemplares selecionados para a análise, cujos planos de expressão são necessariamente sincréticos. Vejamos primeiramente o texto 1:

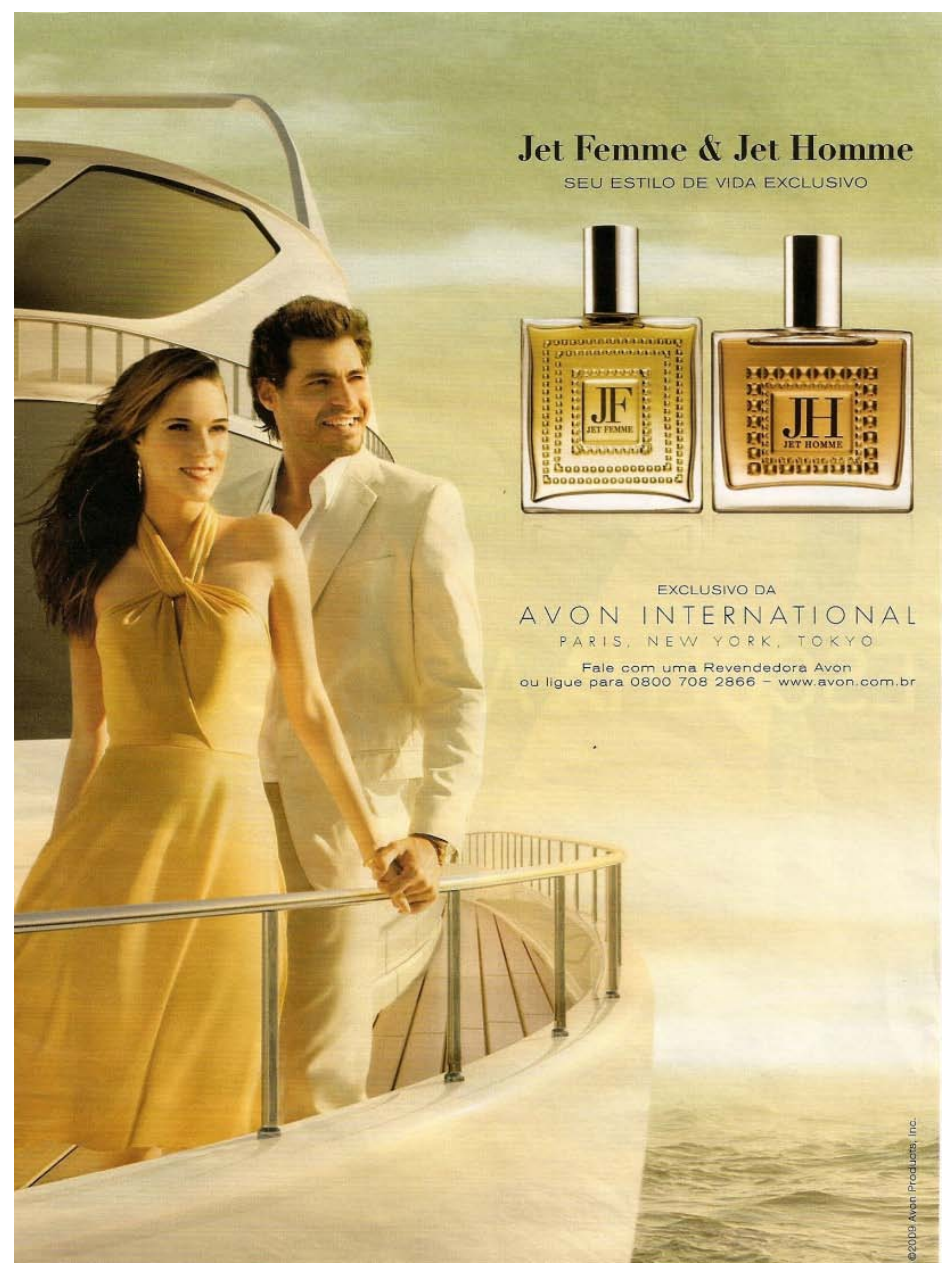

No texto 1, temos o exemplo do uso de elementos verbais e icônicos: as palavras nos auxiliam a chegarmos ao conteúdo, mas é fundamental atentar para as imagens, as quais se revelam essenciais para o entendimento do sentido. Trata-se de uma campanha publicitária de perfumes masculino e feminino da empresa de cosméticos Avon, veiculada em setembro de 2009 na revista Época. Temos no plano de expressão um casal bem trajado encostado na amurada de um barco durante um possível passeio marítimo. No canto superior direito do anúncio temos os dizeres “Jet Femme \& Jet Homme”, (Ser Mulher \& Ser Homem), e um pouco abaixo a frase "Seu estilo de vida exclusivo”. A primeira inscrição trata do nome do produto, os perfumes, a segunda consiste em uma espécie de slogan. Já os dizeres abaixo da figura dos frascos de perfume fornecem o nome da marca e o meio de contato. 
Com base na conjunção entre as imagens e as palavras trabalhadas no plano de expressão, constatamos que os perfumes Jet Feme e Jet Homme oferecem ao actante um status de exclusividade através do qual, o actante se distinguirá das demais pessoas que não consomem o produto, conforme temos nos dizeres: "Seu estilo de vida exclusivo.” Desse modo, os perfumes oferecem não apenas uma fragrância, mas um status social único e exclusivo, uma vida de elegância e beleza, que vemos ilustrada através das imagens.

Podemos articular no quadrado semiótico a oposição semântica de base /coletividade/ vs /individualidade/, uma vez que os perfumes anunciados oferecem a possibilidade do actante se destacar em meio a coletividade realçando sua individualidade. Uma particularidade obtida com a aquisição de um produto que garante um social exclusivo. Outra categoria que se agrega a esta primeira é /inclusividade/ vs /exclusividade/, já que o status social conseguido pelo actante é exclusivo, sendo excluídos aqueles que não adquirem o perfume. O que articulamos no quadrado semiótico da seguinte maneira:

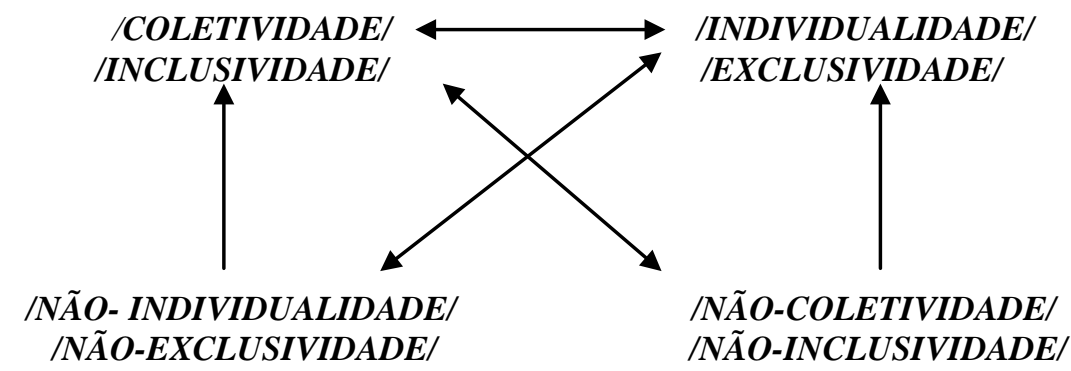

Como os valores /individualidade/ e /exclusividade/ são buscados em detrimento daqueles que são evitados /coletividade/ e /inclusividade/, esses últimos são valores disfóricos, de modo que os actantes buscam uma relação de conjunção com os valores eufóricos, aqueles considerados positivos no/pelo texto, que são os termos /individualidade/ e lexclusividade/.

Dessa maneira, os perfumes Jet Femme e Jet Homme se tornam objetos valores (Ovs) positivos, com os quais os actantes conseguem estabelecer uma relação de conjunção com os valores eufóricos /individualidade/ e /exclusividade/. Essa conjunção, por sua vez, não se realiza através de um simples salto do termo negativo para o positivo, mas segue um percurso que também pode ser representado no quadrado semiótico, o que ilustramos a seguir: 


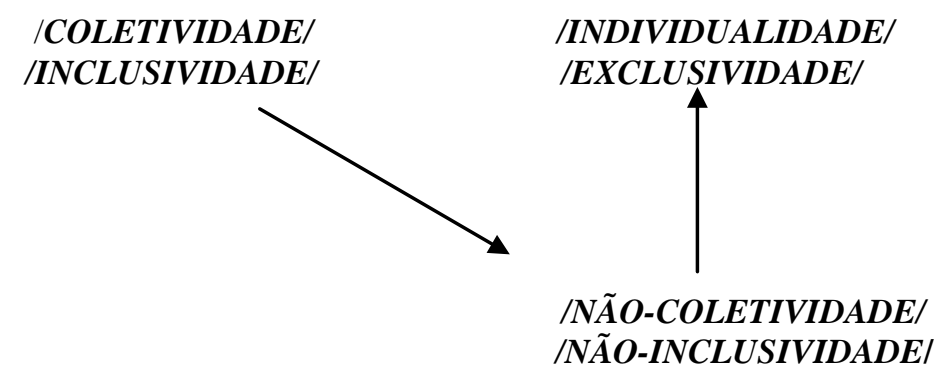

O esquema acima pode ser lido da mesma maneira que uma sequência narrativa: o casal de actantes parte de um estado de /coletividade/ e /inclusividade/, condição das pessoas comuns, sem nenhuma característica que os distingam dos outros membros de uma classe ou grupo, passam por um estado de /não-coletividade/ e /não-inclusividadel chegando, finalmente, ao estado eufórico de /individualidade/ e /exclusividade/.

No nível narrativo do texto, temos um PN de sedução. A sedução em termos semióticos consiste em uma forma de manipulação na qual são elogiadas as qualidades do actante de modo a provocar nele a confiança necessária para executar uma ação desejada. Nesse caso, são elogiadas as qualidades dos actantes como sujeitos cujas qualidades os tornam merecedores de adquirir o produto. Mas vejamos esse PN de sedução passo a passo.

Primeiramente, um destinador-manipulador, a empresa de cosméticos, manipula o casal de actantes levando-os a crer que podem executar uma performance. Em seguida, após executada a performance, o destinador-manipulador atua como um destinador-julgador que sanciona os destinatários-sujeitos em dois níveis. Primeiramente temos uma sanção cognitiva, em que o destinador-julgador reconhece que a performance foi executada, e, num segundo momento, temos a sanção pragmática, na qual os actantes conquistam os valores desejados. O que ilustramos no quadro a seguir:

\section{Quadro 2:}

\begin{tabular}{|c|c|c|c|c|}
\hline Manipulação & Competência & Performance & $\begin{array}{l}\text { Sanção } \\
\text { cognitiva }\end{array}$ & $\begin{array}{l}\text { Sanção } \\
\text { pragmática }\end{array}$ \\
\hline $\begin{array}{l}\text { Os sujeitos- } \\
\text { destinatários têm } \\
\text { suas qualidades } \\
\text { elogiadas e são }\end{array}$ & $\begin{array}{l}\text { Os sujeitos- } \\
\text { destinatários } \\
\text { acreditam } \\
\text { possuir uma }\end{array}$ & $\begin{array}{l}\text { Os sujeitos- } \\
\text { destinatários } \\
\text { adquirem e usam } \\
\text { o perfume }\end{array}$ & $\begin{array}{l}\text { O destinador - } \\
\text { julgador } \\
\text { reconhece que a } \\
\text { performance foi }\end{array}$ & $\begin{array}{l}\text { O destinador- } \\
\text { julgador concede } \\
\text { aos actantes os } \\
\text { valores buscados }\end{array}$ \\
\hline
\end{tabular}




\begin{tabular}{|l|l|l|l|l|}
\hline $\begin{array}{l}\text { manipulados a } \\
\text { buscarem o } \\
\text { perfume }\end{array}$ & $\begin{array}{l}\text { competência } \\
\text { para realizar a } \\
\text { performance }\end{array}$ & executada & $\begin{array}{l}\text { com a aquisição } \\
\text { do perfume }\end{array}$ \\
\hline
\end{tabular}

Passando ao nível discursivo, temos uma enunciação em primeira pessoa (EU) que se refere a si mesmo como uma terceira pessoa (ELE), caracterizando uma embreagem, que é o efeito de retorno a enunciação. Já as categorias de espaço e tempo não são evidenciadas, não havendo um tempo preciso (passado ou presente) nem um espaço definido da enunciação. Desse modo, fica instalada uma enunciação com efeito de subjetividade e objetividade, na qual o enunciador mostra o percurso dos actantes como um exemplo de um status social que pode ser alcançado pelo receptor da mensagem.

No subcomponente temático do nível discursivo, encontramos a oposição elegância vs vulgaridade. O termo elegância é representado pelos trajes do casal e pela figura do barco de passeio no qual se encontram. O termo vulgaridade, por sua vez, remete a vulgar, que designa originalmente aquilo que é do povo, o que é coletivo e desse modo se opõe ao termo elegância, que no texto, está relacionado com os valores exclusivos oferecidos pelo perfume anunciado e pelos trajes usados pelos modelos do anúncio. Lembramos que os termos de uma oposição semântica, seja no nível discursivo, seja no nível fundamental, não precisam estar explícitos no texto, já que a presença de um deles pressupõe o seu oposto. Assim, o tema da vulgaridade é pressuposto a partir da presença de seu contrário, o tema da elegância.

A montagem do quadrado semiótico com as oposições semânticas de base e com as oposições temáticas, por sua vez é apresentada a seguir:

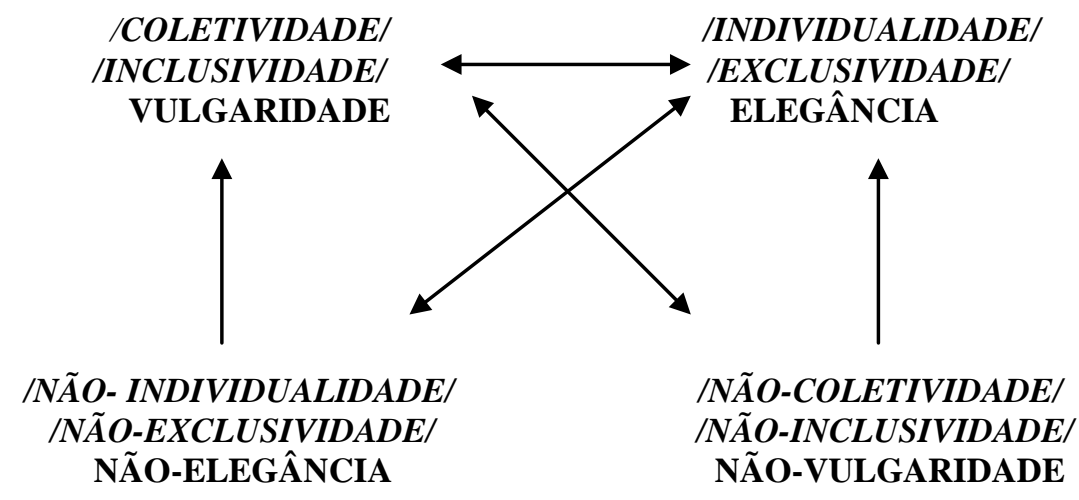

E dessa maneira, os actantes da narrativa seguem o seguinte percurso: 


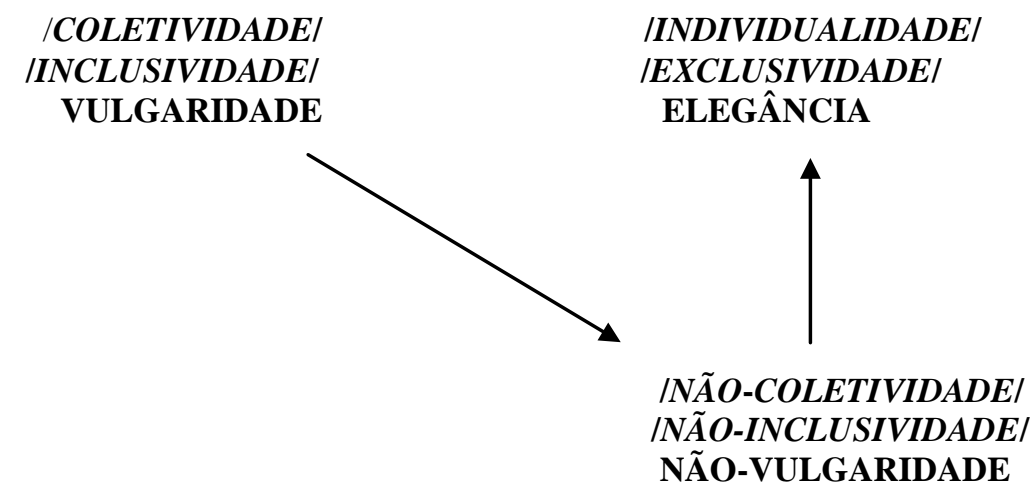

Uma vez concluída a análise do texto 1, passemos agora a abordagem do texto 2 . No primeiro texto, pudemos observar como os elementos verbais e os não-verbais se imiscuem para construir uma complexa estrutura de sentidos. Por sua vez, os conhecimentos que pudemos levantar na abordagem do primeiro texto, agora nos serão úteis para a análise do texto 2, que traz como único elemento verbal o nome de uma grife ou de uma loja, conforme podemos ver na ilustração a seguir: 


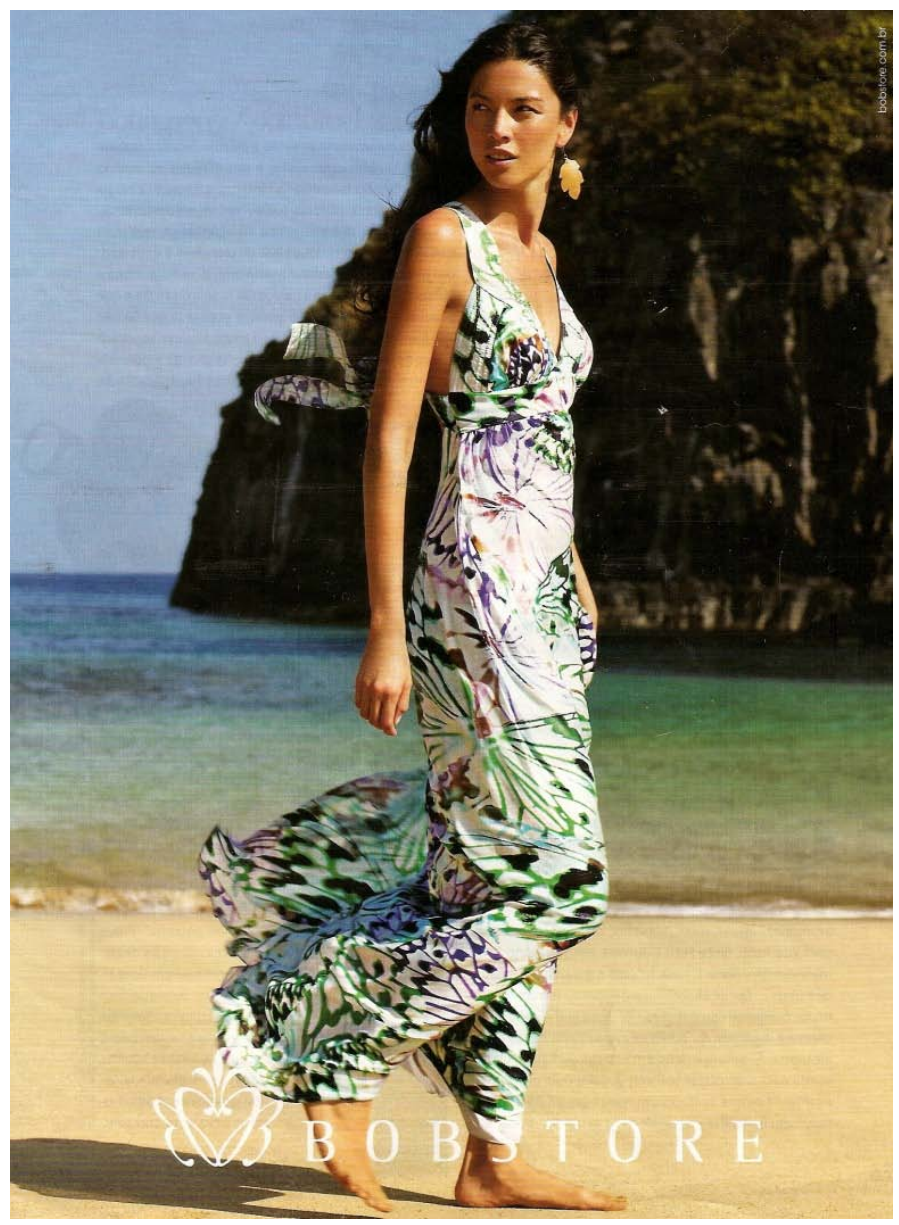

No texto 2, temos a foto de uma modelo descalça usando um vestido longo que parece se colar ao corpo por ação do vento. A composição da fotografia é simples, há apenas um esquema do tipo figura (a modelo) e fundo (o recorte de uma paisagem litorânea). Ao pé da imagem temos o nome da grife ou loja, Bob Store, que, supostamente comercializa o vestido anunciado.

Um texto tão parcamente verbal nos impõe certa dificuldade de análise, mas, ao mesmo tempo, não deixamos de compreender nele uma mensagem e, assim, gerarmos uma interpretação. Essa interpretação imediata que fazemos nos mostra que o texto de fato se encontra pleno de significação, embora suas estruturas internas de sentido não sejam notadas por um leitor menos informado ou menos disposto a buscar uma interpretação mais porfunda do texto. Para tanto demonstramos a seguir a complexa rede de sentidos que se encontra no texto.

Como pode ser observado, temos no substrato visual apenas uma moça de vestido caminhando na praia. O cenário nos sugere uma espécie de paraíso natural à beira-mar, remetendo a presença da natureza. Por outro lado, o único elemento artificial que encontramos na foto é justamente o vestido e o brinco, na orelha esquerda da modelo. Tanto o vestido 
quanto o brinco não nos parecem um produto arrojado, já que têm a aparência de produtos artesanais.

Esses elementos, por essa via, nos legam a oposição fundamental /natureza/ vs /cultura/, sendo que o termo /natureza/ é realizado pelo cenário natural, e pela própria modelo, enquanto que o termo /cultura/ se realiza com a figura do vestido e do brinco. Essa oposição remete ao domínio da natureza que o homem desenvolveu no curso de uma evolução, passando, assim, de um estado de objeto da natureza para um estado de sujeito, já que, dominando-a o homem passou a ser um produtor de artefatos e de seus próprios meios de sobrevivência.

A representação dessa categoria no quadrado semiótico se faz da seguinte maneira:

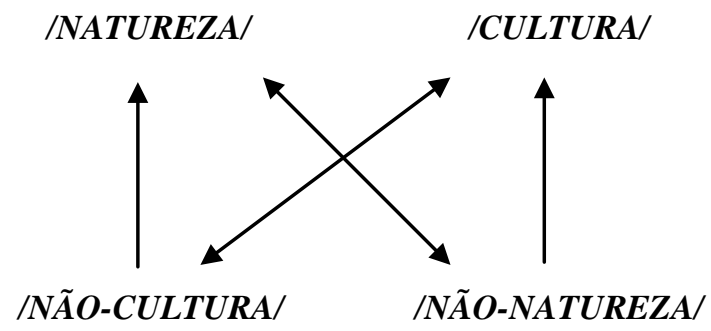

Uma primeira observação que se faz importante sobre essa montagem é que um texto pode se caracterizar pela presença de termos complexos, os quais ocorrem quando um elemento do texto realiza não apenas um dos termos da oposição semântica de base, mas os dois termos da categoria. No texto 2, o termo /natureza/ recebe uma axiologização positiva, tornando-se eufórico. Logo, a natureza é um valor buscado pela actante, e não um valor negativo que ela procura evitar. O que a grife propõe é justamente a possibilidade de reencontro com a natureza através da aquisição de um produto. Desse modo, a modelo que vemos na foto se torna um termo complexo, já que reúne em si tanto o estado de /natureza/ quanto o de /cultura/.

A ocorrência de um termo complexo, por sua vez, não significa que não haja um percurso narrativo, uma transformação de estado da actante. Para tanto vejamos a colocação desses elementos num programa narrativo:

Quadro 3:

\begin{tabular}{|l|l|l|l|l|}
\hline Manipulação & Competência & Performance & $\begin{array}{l}\text { Sanção } \\
\text { cognitiva }\end{array}$ & $\begin{array}{l}\text { Sanção } \\
\text { pragmática }\end{array}$ \\
\hline
\end{tabular}




\begin{tabular}{|l|l|l|l|l|}
\hline $\begin{array}{l}\text { A actante tem } \\
\text { suas qualidades } \\
\text { elogiadas e é } \\
\text { manipulado a } \\
\text { buscar o vestido }\end{array}$ & $\begin{array}{l}\text { A actante } \\
\text { acredita } \\
\text { possuir uma } \\
\text { competência } \\
\text { para realizar a } \\
\text { performance }\end{array}$ & $\begin{array}{l}\text { A actante adquire } \\
\text { o vestido }\end{array}$ & $\begin{array}{l}\text { O destinador- } \\
\text { julgador } \\
\text { reconhece que a } \\
\text { performance foi } \\
\text { executada }\end{array}$ & $\begin{array}{l}\text { O destinador- } \\
\text { julgador concede } \\
\text { a actante os } \\
\text { valores buscados } \\
\text { com a aquisição } \\
\text { do vestido. }\end{array}$ \\
\hline
\end{tabular}

Primeiramente, o destinador manipulador, a grife Bob Store, manipula a actante, a modelo, por meio de sedução, uma vez que elogia suas qualidades dispondo-a a adquirir o produto anunciado. Em um segundo momento, o sujeito-destinatário, a actante, acredita possuir uma competência: ela acredita merecer e adquirir o vestido. Em seguida, a actante realiza a performance de adquirir o produto anunciado. Com a sanção cognitiva o destinadorjulgador reconhece que a performance foi realizada, e com a sanção pragmática o destinadorjulgador confere a actante o conforto e o bem-estar proporcionados pelo produto vestido.

Podemos notar que o vestido se torna um objeto-valor (Ov) positivo, já que é através dele que a nossa actante consegue reestabelecer uma relação de conjunção com o termo eufórico /natureza/. Desse modo, podemos articular no quadrado semiótico o seguinte arranjo:

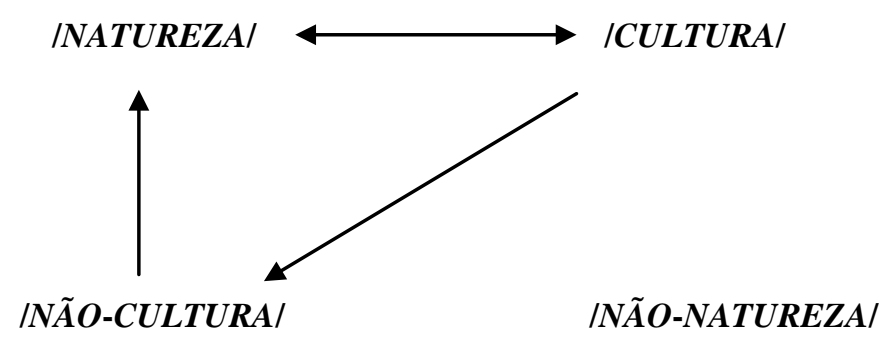

No nível discursivo, temos novamente uma embreagem, efeito através do qual o enunciador refere a si mesmo como em primeira pessoa, como se o enunciador estivesse afastado de sua enunciação. Uma vez determinada a presença de uma primeira pessoa que se refere como uma terceira, observamos também que a categoria de espaço é preenchida com o LÁ, já que a narrativa ocorre em um outro espaço, indeterminado, e a categoria de tempo é preenchida com incerteza, já que não sabemos se se trata de uma ocorrência no tempo presente ou passado.

Ainda no nível discursivo, os temas e figuras, sendo que a oposição temática: conforto vs desconforto se faz presente. O termo conforto é dado pela leveza e simplicidade das pecas de roupa usadas pela modelo, e que a permitem usufruir do cenário natural em que se 
encontra. Por seu turno, o termo desconforto é recuperado através de pressuposição graças à existência, no texto, de seu oposto. O termo desconforto, assim, é sugerido por uma peça de roupa menos adequada à interação da modelo com o cenário natural, roupa que não aparece, mas, ao mesmo tempo, é sugerida, pelo anúncio. Oposição montada a partir dos temas da beleza, do conforto, e do bem-estar dados pelo clima quente da praia. Os temas, por sua vez, são figurativizados pela paisagem, pelo vestido, pelo vento que imaginamos agitar o vestido. O que montamos no quadrado semiótico da seguinte maneira:

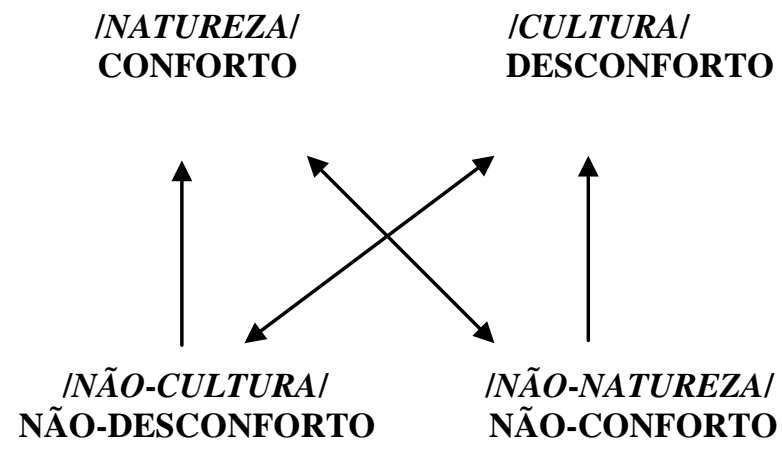

Nota-se, portanto, que a Bob Store se projeta no texto como uma instância distanciada que oferece valores axiológicos para a actante como o conforto ou bem-estar. O que pode ser representado no quadrado semiótico da seguinte maneira:

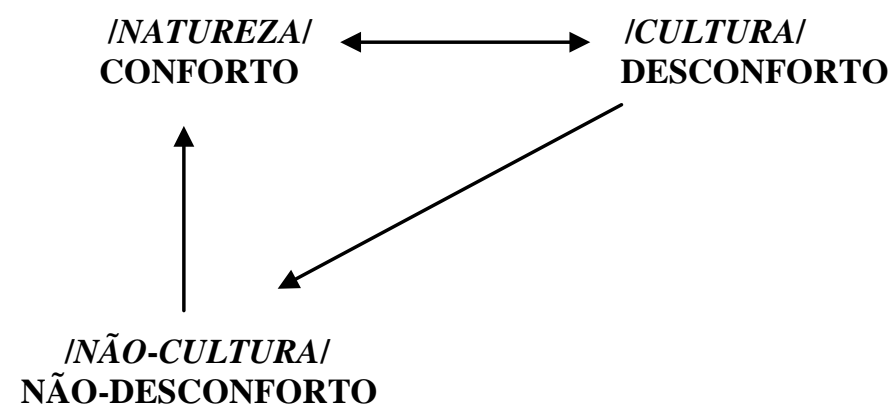

Nos textos 1 e 2, a aparente simplicidade e, poderíamos dizer “defasagem” de sentidos, não resiste a uma análise mais cuidadosa e complexas estruturas de significação se mostram embasando percursos narrativos não menos complexos. Pelo viés da semiótica, essa complexidade de sentidos não se restringe aos textos verbais, mostrando-nos a possibilidade de ler, interpretar também textos sincréticos. Esse fato se reforça se lembrarmos que tanto em 
textos estéticos quanto em utilitários, o signo visual aparece como coadjuvante de uma mensagem, e, não raro, como a própria mensagem.

Lembremos da onipresença do elemento visual na publicidade, nas artes, nos livros didáticos modernos, entre outros. O signo visual acompanha os diversos tipos/gêneros de texto. É nessa perspectiva que aproveitamos para frisar a importância da semiótica o âmbito dos estudos linguísticos. Assim, a semiótica se coloca nos estudos da linguagem como mais uma ferramenta eficaz para se compreender a significação de textos sincréticos.

\section{REFERÊNCIAS}

BERTRAN, Denis. Caminhos da Semiótica Literária. Trad. Grupo CASA. Bauru: Edusc, 2003.

FIORIN, José Luiz. Sendas e veredas da semiótica narrativa e discursiva. In: DELTA-Revista de Documentação de Estudos em Lingüística Teórica e Aplicada. São Paulo, v. 15, n. 1. 1999. p. 1-13.

GREIMAS, Algirdas; COURTÉS, Joseph. Sémiotique: Dictionnaire Raisonné de la Theorie du Langage, Tome I. Paris: Hachette, 1979.

HERNADES, Hilton. Duelo: a publicidade da tartaruga da Brahma na Copa do Mundo. In: LOPES, I. C. e HERNANDES, N. (orgs.). Semiótica: objetos e práticas. São Paulo: Contexto, 2005. p. 227-44.

HJELMSLEV, Louis. Prolégomènes à une theorie du langage. Tradução de Anne-Marie Leonard. Paris: Minuit, 1968. 
